\title{
UM ESTUDO PRÁTICO SOBRE CÉLULAS MICRO E MACROSCÓPICAS, UNIVERSIDADE DO ESTADO DA BAHIA- UNEB, CAMPUS XXIV, XIQUE-XIQUE-BAHIA
}

\author{
Cleide Cruz Soares \\ Universidade do Estado da Bahia \\ cleide_csoares@hotmail.com \\ Suélen de Azevedo \\ Universidade do Estado da Bahia \\ suazevedo2011@hotmail.com \\ Darcy Ribeiro de Castro \\ Universidade do Estado da Bahia \\ darcyrcastro@gmail.com
}

\begin{abstract}
Resumo
Este trabalho é resultante de parte de um curso de extensão sobre a biologia celular prática realizada no Laboratório Multidisciplinar (LM) da Universidade do Estado da Bahia (UNEB), Campus XXIVXique-Xique-BA em 2017 com 26 estudantes dos Cursos de Engenharia de Pesca e de Engenharia Sanitária e Ambiental. Envolve um estudo sobre estrutura e função de células e/ou estruturas microscópicas e macroscópicas. Teve como objetivo caracterizar estruturas pluricelulares microscópicas ou macroscópicas (o grão de pólen e o óvulo da flor da erva beijo- de- frade) ou pluricelulares macroscópicas pequenas (o fio de cabelo e o óvulo da banana), células macroscópicas (o alvéolo da laranja e a fibra de algodão). Para isso, foram realizadas 6 atividades práticas. As amostras foram coletadas em seu meio natural (rio São Francisco), no quintal de casa e observadas no laboratório a olho nu, com o auxilio do Microscópio Estereoscópico Binocular (MEB) e do Microscópio Óptico Comum (MOC), sob aumentos de 4, 10, 20 e 40x. Os registros foram feitos com um celular digital e nota de campo e os dados analisados conforme os referenciais da área. Caracterizou-se em geral o tamanho, a estrutura, a forma e/ou organização células/ seres vivos com suas respectivas funções e implicações para a formação dos profissionais nas áreas de engenharia de pesca, engenharia sanitária e ambiental e cursos afins. Ademais, indicaram-se a necessidade da continuidade do estudo e o desenvolvimento novos trabalhos na área, a fim de contribuir para ampliação do conhecimento sobre a biologia celular.

Palavras-chave: Atividades práticas. Biologia celular. Célula/ser vivo. Células microscópicas. Células macroscópicas.

\section{A PRACTICAL STUDY ON MICRO AND MACROSCOPIC CELLS, UNIVERSITY OF THE STATE OF BAHIA-UNEB, CAMPUS XXIV, XIQUE- XIQUE, BAHIA}

\begin{abstract}
This work is the result of part of an extension course on the cell biology practice held at the Multidisciplinary Laboratory (LM) of the Universidade do Estado da Bahia (UNEB), Campus XXIVXique-Xique, Bahia in 2017 with 26 students of the engineering courses fishing and sanitary and environmental engineering. Involves a study on structure and function of cells and/or microscopic and macroscopic structures. Aimed to characterize microscopic or macroscopic multicellular structures (the grain of pollen and egg flower grass kiss-of-Friar) or macroscopic small multicellular (the hair and the egg of banana), macroscopic cells (alveoli of Orange and cotton fiber). For this, 6 were carried out practical activities. The samples were collected in your natural environment (São Francisco River), in the backyard and observed in the lab to the naked eye, with the help of Binocular
\end{abstract}

Cidadania em Ação; Revista de Extensão e Cultura, Florianópolis (SC), v. 3, n. 2, jul./dez. 2019. 
Stereoscopic Microscope (MEB) and Optical Microscope (MOC), under 4 increases, 10, 20 and 40. The records were made with a digital cell phone and note field and the parsed data as the benchmark. Was characterized in general size, structure, shape, and/or organization cells/living beings with their respective functions and implications for the training of professionals in the areas of fishing engineering, sanitary and environmental engineering and related courses. In addition, indicated the necessity of the continuity of the study and the development of new works in the field, in order to contribute to expanding the knowledge of cell biology.

Keywords: Practical activities. Cell biology. Cell/ living being. Microscopic organisms. Macroscopic cells.

\title{
UN ESTUDIO PRÁCTICO SOBRE CÉLULAS MICRO Y MACROSCÓPICOS, UNIVERSIDADE DO ESTADO DA BAHIA-UNEB, CAMPUS XXIV, XIQUE- XIQUE, BAHIA
}

\begin{abstract}
Resumen
Esta obra es el resultado de parte de un curso de extensión sobre la práctica de la biología de la célula llevó a cabo en el laboratorio multidisciplinario (LM) de la Universidade do Estado de Bahía (UNEB), Campus XXIV-Xique-Xique, Bahia en 2017 con 26 alumnos de los cursos de ingeniería Ingeniería pesquera y sanitaria y ambiental. Consiste en un estudio sobre la estructura y función de las células o estructuras microscópicas y macroscópicas. Pretende caracterizar estructuras multicelulares microscópicas o macroscópicas (el grano de polen y óvulo de la flor de la hierba beso de fraile) o macroscópicos multicelulares (el pelo y el huevo de plátano), las células macroscópicas (alvéolos de Fibra de naranja y algodón). Para ello, 6 se llevaron a cabo actividades prácticas. Las muestras fueron recolectadas en su entorno natural (río de São Francisco), en el patio trasero y observaron en el laboratorio a simple vista, con la ayuda del microscopio estereoscópico Binocular (MEB) y microscopio óptico (MOC), en incrementos de 4, 10, 20 y 40. Los registros se hicieron con un teléfono celular digital, campo de notas y los datos analizados como el punto de referencia. Fue caracterizado en tamaño, estructura, forma y organización las células estar cosas con sus respectivas funciones y las implicaciones para la formación de profesionales en las áreas de ingeniería pesquera, ingeniería sanitaria y ambiental y cursos relacionados. Además, indica la necesidad de la continuidad del estudio y el desarrollo de nuevas obras en el campo, con el fin de contribuir a ampliar el conocimiento de la biología celular.
\end{abstract}

Palabras clave: Actividades prácticas; Biología de la célula. Celular/estar vivo. Células microscópicas. Células macroscópicas. 


\section{INTRODUÇÃO}

Os organismos unicelulares podem ser microscópicos ou macroscópicos. A fibra de algodão, alvéolos de laranja/limão, a gema do ovo e as células da bainha da bananeira são estruturas macroscópicas unicelulares, masintegrantes do corpo de organismos pluricelulares macroscópicos. Há animais pluricelulares microscópicos ou macroscópicos (rotíferos e cladocera) e também seres unicelulares macroscópicos, a exemplo da bactéria Epulopiscium fishelsoni e a alga Acetabularia crenulata ou Acetabularia orbiculata. Estes podem ser assuntos que os alunos da Educação Básica têm dificuldades de compreender por se tratar de conceitos abstratos: pluricelular microscópico e unicelular macroscópico (AUTOR, 2010; 2014).

Essas limitações podem continuar no Ensino Universitário, tendo em vista a pouca experiência dos estudantes ingressos com o Microscópio Óptico Comum (MOC) ou mesmo com Microscópio Estereoscópico Binocular (MEB) ou lupa, falta de noção de escala etc. Neste sentido, descrever a estrutura micro e macro destes organismos/células na sua relação com a sua funcionalidade pode contribuir para a formulação de uma melhor compreensão de alunos de cursos de graduação para o referido assunto (RIBEIRO; BARBERI, 2005).

$\mathrm{O}$ presente trabalho teve como objetivo caracterizar estruturas pluricelulares microscópicas ou macroscópicas (o grão de pólen e oóvulo da flor da erva beijo- de- frade) ou pluricelulares macroscópicas pequenas (o fio de cabelo e oóvulo da banana), células macroscópicas (o alvéolo da laranja e a fibra de algodão).

\section{METODOLOGIA}

Trata-se de uma pesquisa investigativa educacional associada ao trabalho extensionista prático de laboratório a partir da observação estruturada, realizada no Laboratório Multidisciplinar (LM) da Universidade do Estado da Bahia (UNEB), Campus XXIV- Xique-Xique-BA em 2017 com 26 estudantes dos Cursos de Engenharia de Pesca e de Engenharia Sanitária e Ambiental. Para realização das atividades práticas sobre estrutura células micro e macroscópicas, usaram-se os seguintes materiais: Microscópio Óptico Comum (MOC), Microscópio Estereoscópico Binocular (MEB) ou lupa, fibra de algodão (Gossypium hirsutum L), alvéolos de laranja e fio de cabelos, grão de pólen e óvulo da flor da erva "beijo-de-frade" (Impatiens balsamina L), óvulo de banana (Musa spp.), frascos de polietileno (500 ml), solução de Formalina - Álcool etílico - Ácido acético glacial (FAA), pipeta graduada, lâminas microscópicas, lamínulas, conta-gotas, álcool, estilete, celular digital e diário de bordo.

Para fins de nortear o desenvolvimento das atividades práticas, as seguintes questões Cidadania em Ação; Revista de Extensão e Cultura, Florianópolis (SC), v. 3, n. 2, jul./dez. 2019. 
foram levantadas: 1) Como se explica a forma ("garrafinha") ou organização dos alvéolos no endocarpo e a produção do conteúdo liquido?; 2) Qual a estrutura do alvéolo da laranja?; 3)E o seu tamanho a que pode está associado/ 1) Como se explica a forma e/ ou organização da fibra de algodão; 2) Qual a estrutura da fibra do algodão; 3) Qual o seu tamanho e diâmetro?/ 1) Qual a forma e a estrutura do fio do cabelo?; 2) O fio de cabelo ou sua raiz é uma macro célula?; 3) Como ocorre a formação do fio de cabelo?; 4) Há alguma semelhança na sua formação com a fibra de algodão?/ 1) Qual a estrutura/organização do óvulo da banana?; 2) Qual a sua forma e o seu tamanho?; 3) A óvulo da banana não é fertilizado por quê?; 4) Quantos óvulos existem em uma banana?/ 1) Em que região da flor o óvulo é formado; 2) Qual a forma e a estrutura do óvulo; 3) Qual o seu tamanho?; 4) Alguns óvulos são microscópicos e outros macroscópicos?/ 1) Onde se localiza o grão de pólen na flor?; 2) Como se organizam os grãos de pólen e qual a sua forma?; 3) Qual a estrutura e o tamanho do grão de pólen?; 4) O grão de pólen e o óvulo são os gametas responsáveis pela fecundação no vegetal?.

As questões acima foram organizadas em bloco de tríades e quartetos ( 2 tercetos, 4 quartetos e 2 tercetos). Elas acompanham a sequência das atividades práticas realizadas. Intenta obedecer à ordem de organização dos seres vivos a partir da célula, bem como do tamanho crescente relativo das estruturas observadas (do alvéolo de laranja ao óvulo vegetal).

Como instrução geral, teve-se a sequência de atribuições: as observações das células/seres vivos foram feitas a olho nu, com auxílio da MEB e da MOC. Em MEB foi considerado o aumento de 10x e em MOC, os aumentos gradativos de 4x, 10x, 20x e 40x. No final das observações, selecionaram-se apenas os aumentos que forneceram as melhores imagens (clareza, precisão etc.). Foram introduzidas gotas de água sobre a lâmina para observação das amostras em MOC. Cobriu-as com lamínulas, a fim de evitar o seu atrito com as objetivas e facilitar a obtenção das imagens esperadas. Esse trabalho foi realizado em 4 etapas, a saber:

1.1 No primeira etapa foram observados o alvéolo da laranja e a fibra do algodão. O alvéolo da laranja (Citrus sp.): as regiões do epicarpo e mesocarpo foram separadas manualmente com o auxílio de um estilete. Igualmente, o endocarpo (gomos) teve a membrana totalmente removida para que se tivesse acesso aos alvéolos. Os alvéolos individualizados foram observados primeiramente a olho nu, depois foram dispostos num vidro de relógio e observados com uma lupa (aumento de 10x). Em seguida, os alvéolos foram transferidos para uma lâmina e observados em MOC com aumentosgradativos de 4x, 
10x, 20x e40x;

1.2 A fibra do algodão (Gossypium hirsutum $L$ ): o emaranhado de fibras foi desfeito manualmente, possibilitando a sua individualização. A olho nu observou-se a cutícula da fibra, depois a fibra foi observada com auxílio do MEB (aumento de 10x) e do MOC (aumentos de 4x, 10x, 20x e 40x).

2) Na segunda etapa foram observadas o óvulo da banana (Musa spp.) e o fio do cabelo (Homo sapiens).

2.1 O óvulo da banana (Musa spp.): com auxílio de um estilete, cortou-se a banana em fatias para fins de possibilitar a retirada de alguns óvulos com uma pinça. Os óvulos foram colocados num vidro de relógio e visualizados com apoio de um MEB (aumento de 10x). Em seguida, esses foram transferidos para uma lâmina na qual gotas de água foram adicionadas com o auxílio de um conta-gotas e inseriu-se a lamínula sobre a amostra que foi visualizada em MOC (aumentos de 4x, 10x, 20x e 40x);

2.2 O fio de cabelo (H. sapiens): extraiu-se o fio de cabelo humano com o devido cuidado para que o folículo capilar (bulbo) também estivesse presente na amostra. A amostra foi disposta num vidro de relógio e observada com auxilio de um MEB (aumentos de 10x), e, por fím, ao microscópio óptico (aumentos de 10x, 20x e 40x);

3) Na terceira etapa foram observados o grão de pólen e o óvulo vegetalflor da erva "beijo- de- frade" (Impatiens balsamina L).

3.1 O pólen da flor: Foi retirado o pólen da flor da erva "beijo-de-frade" (Impatiens balsamina L) e espalhou-se este entre os dedos, com uma visualização a olho nu de um pó branco (pólen pulverulento) que foi transferido para um vidro de relógio (amostra). Em seguida, observou-se a amostra com auxílio de um MEB (aumento de 10x), e, por fim, uma porção menor da amostra foi observada com o MOC (aumentos de 10x, 20x e 40x). Para isso, o grão de pólen foi colocado numa lâmina, uma gota d'água foi adicionada com o conta-gotas e coberto por uma lamínula;

3.2 O óvulo vegetal: Para a amostragem foi utilizada a flor da erva "beijo-defrade" (Impatiens balsamina L). Com o auxílio do estilete foram retirados os óvulos da placenta, que está localizada na região interna do carpelo. Esses óvulos foram alocados para um vidro de relógio e observados com apoio de um MEB (aumento de 10x). Em seguida, colocou-os numa lâmina, adicionou uma gota de água e cobriu-lhes com uma lamínula. Por fim, observou-os com auxilio do MOC sob aumentos respectivos de 10x, 20x e 40x.

Os registros das três etapas do trabalho de laboratório foram feitos com um celular digital e nota de campo. Analisaram-se as imagens e anotações obtidas mediante referenciais

Cidadania em Ação; Revista de Extensão e Cultura, Florianópolis (SC), v. 3, n. 2, jul./dez. 2019. 
apresentados. Buscou-se, com isso, caracterizar as células/seres vivos e responder aos questionamentos levantados. Para respondê-los usou os conceitos de estrutura e função vegetal individualmente ou associados.

\section{RESULTADOS E DISCUSSÃO}

O trabalho prático extensionista envolveu uma discussão preliminar sobre termos como forma, tamanho, organização, localização/habitat e funcionalidade de organismos/células. São conceitos usados comumente no dia a dia dos estudantes, mas pouco explorados na sala de aula.

\section{O ALVÉOLO DA LARANJA}

Os vegetais do gênero Citrus sp., família Rutaceae, a exemplo do limão, laranja e tangerina têm o fruto do tipo baga (hesperídio) cuja origem é a partir de um ovário súpero multicarpelar. O seu epicarpo (casca) é coriáceo e delgado com numerosas glândulas oleíferas; o mesocarpo (membrana branca abaixo da casca) é esponjoso; o endocarpo é membranáceo e dividido em gomos ou vesículas compostas de tricomas, pêlos sucosos ou células glandulares (alvéolos) (FERRI, 1985) que continuam com atividade metabólica constante durante a maturação (respiração e produção de etileno).

O gomo da laranja, visualizado a olho nu, apresenta dezenas de alvéolos ligados por suas paredes celulares. Para estes autores, tais arranjos são adaptações que permitem as trocas gasosas do fruto com a atmosfera. Estas células são papidiforme (forma de garrafa) com vacúolos desenvolvidos para armazenamento do suco rico, principalmente, em ácido cítrico que mantém o sabor azedo do fruto.

Percebeu-se que o alvéolo observado separadamente facilita a descrição de suas características particulares. Trata-se de uma célula macroscópica (cerca de $10 \mathrm{~mm}$ ) cuja visualização é ampliada levemente em Microscopia Estereoscópica Binocular (MEB) ou lupa, com aumento de 10x (fig.01). Deste modo, observou-se a sua parede celular com maior nitidez (em relação a olho nu), a qual delimita o espaço celular do alvéolo que tem formato parecido com uma gota de água ("garrafinhas" ou "bolsas cheias de suco") e uma tonalidade amarelo claro. Sua extremidade é alongada e fina na direção da membrana do endocarpo próxima ao mesocarpo e mais larga no seu centro (fig.01) ou mais larga próximo ao endocarpo e mais estreita próxima ao seu centro. Esta organização espacial dos alvéolos dentro do endocarpo pode estar associada a sua função, que é a de se prender aos demais alvéolos, deixar espaços para que as sementes se alojem, além de permitir a realização da atividade metabólica com a maturação (respiração e síntese do etileno), tendo vantagens em 
relação à velocidade dos gases em meio aquoso intracelular (FERRI, 1985; CALBO, MORETTI \&HENZ, 2007).

O alvéolo visualizado com auxilio de um Microscópio Óptico Comum (MOC) com um aumento de 40x apresenta uma camada rígida (parede celular) e espessa (fig. 02), capaz de reter o líquido presente, sendo este líquido composto de vitaminas (A, B e C) e carboidratos. Abaixo destacamada rígida existe a membrana celular, que não pode ser visualizada em MOC.

Figuras 01 e 02: Alvéolos da laranja (Citrus sp.) visualizados,

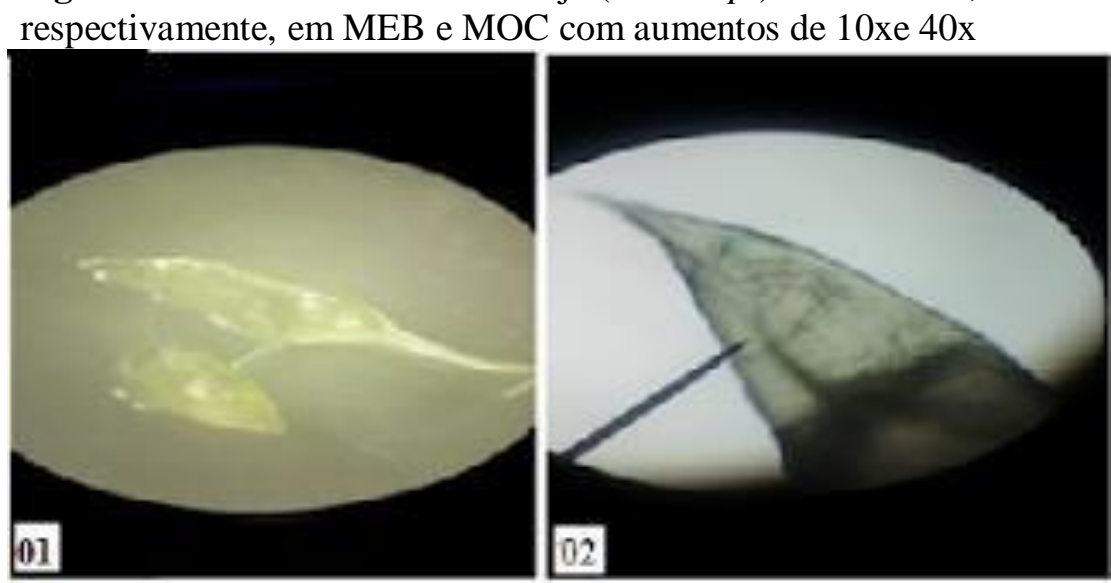

Fonte: Autor.

A partir da atividade prática com o alvéolo da laranja (Citrus sp.), tornou-se possível discutir as seguintes questões (terceto 1): 1) Qual a estrutura do alvéolo da laranja?; 2)Como se explica a forma ("garrafinha") ou organização dos alvéolos no endocarpo e a produção do conteúdo liquido?; 3) E o seu tamanho a que pode está associado?

Em relação à estrutura do alvéolo (questão 1), evidenciou-se uma parede celular que foi ampliada de forma crescente a partir da observação a olho nu, com o auxilio do MEB e do MOC. Destacou-se sobre a sua coloração amarelo claro, sua espessura a rigidez, a presença de vacúolo no citoplasma e de uma membrana plasmática sob a parede celular (não evidenciados em MOC).

Quanto à forma celular do alvéolo da laranja (questão 2), percebeu- se que a extremidade alongada do alvéolo disposta na direção da casca da laranja se adere à membrana do endocarpo (célula papidiforme, "garrafinha" ou "gota d' água") ou ao centro do fruto, pode facilitar o alojamento das sementes, manter a unidade entre eles, bem como atividade metabólica nos processos de fotossíntese e respiração.

No que tange a questão 3 (tamanho do alvéolo), discorreu-se sobre uma macro célula cujo tamanho pode está associado à função de armazenamento de vitaminas (A, B e C) e de 
carboidratos usados como fonte de alimento animal que, por sua vez, contribui para a dispersão da sementes e para perpetuação da espécie. Além disto, pontuou-se que o alvéolo contribui para do processo de nutrição do fruto durante o seu desenvolvimento. $\mathrm{O}$ armazenamento é decorrente de um vacúolo que preenche grande parte do citoplasma. Em síntese, estrutura, a forma e o tamanho do alvéolo se relacionam com uma especialidade do tecido que compunha o fruto (em nível de estrutura) e que se somam para atender a funcionalidade vegetal (reprodução, respiração, fotossíntese). A explicação sobre a relação entre turgência dos alvéolos e sua composição em nível de citoplasma (organelas, citoesqueleto, membrana, nutrientes) em frutos jovens e maduros fica na deriva de estudos posteriores nessa área.

\section{A FIBRA DE ALGODÃO (GOSSYPIUM HIRSUTUM L)}

A fibra de algodão é constituída por uma única célula vegetal completa, ou seja, é uma fibra unicelular podendo ter tamanho longo ou curto. Tem como função a proteção da semente imatura e auxiliar em sua dispersão, após seu desenvolvimento. O comprimento médio da fibra é de $23 / 32 \mathrm{~mm}(23 / 32.000 \mu \mathrm{m})$ e o diâmetro médio de $0,21 \mathrm{~mm}(210 \mu \mathrm{m})$, o que dificulta contagens muito refinadas (TROTMAN, 1984).

Nas células vegetais, existe uma camada de proteção composta de celulose. Entre os componentes dessa camada está o protoplasma vivo e um fluido formado por uma mistura de vários sais minerais, denominados de seiva celular. O protoplasma morre e a seiva desaparece quando a célula alcança a fase madura, deixando uma estrutura quase oca. Com isto, a fibra de algodão morre e o seu conteúdo (seiva e protoplasma) não pode mais ser visto com auxílio do Microscópio Óptico Comum (MOC) ou Microscópio Estereoscópico Binocular (MEB) / lupa, salvo as proteínas e os sais que são restaurados com a evaporação da seiva (TROTMAN, 1984).

A cutícula é a camada mais externa da fibra de algodão e é composta por um fino filme de gorduras, cera e pectinas. Anterior a ela, encontra-se a camada primária, formada principalmente por celulose de modo que as fibrilas estão organizadas em aspecto cruzado. A camada secundária fica próxima do miolo central (lúmen). Esta camada é composta por celulose que constitui a maior parte da fibra e pode ser diferenciada em 3 (três) zonas distintas, sendo elas: a mais externa constituída por fibrilas mais finas e helicoidais; dentro da zona externa está a segunda zona rica em conteúdo celulósico com formato de hélices; a terceira zona só é observada em algodão mais maduro, pois fica localizada ao lado da parede do lúmen e é composto por proteínas e sais minerais resultantes da secagem da seiva celular (TROTMAN, 1984). 
Não foi possível distinguir o tamanho, o diâmetro e o formato das fibras de algodão a olho nu. Identificou-se somente um emaranhado de fibras brancas (unicelulares). Com auxilio da MEB (aumento de 10x), observou-se uma leve separação dos filamentos (fig. 03). Em MOC, aumento de 10x, distinguiu-se com um pouco de mais clareza o comprimento e formas variadas das fibras do algodão (Fig. 04). Em MOC, aumento de 40x (fig. 05), observou-se a camada de celulose que envolve completamente a fibra (TROTMAN, 1984).

Figuras 03, 04 e 05: fibra do algodão (Gossypium hirsutum L) visualizada em MEB (um aumento de 10x) e em MOC (aumentos 10x e 40x), respectivamente.

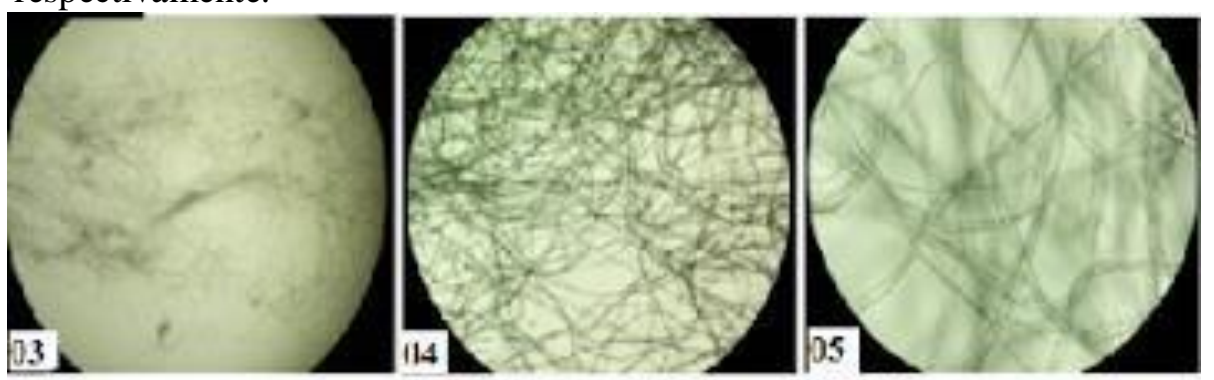

Fonte: Autores.

A partir da atividade prática com a fibra de algodão, tornou-se possível discutir as seguintes questões (terceto2): 1) Como se explica a forma e/ ou organização da fibra de algodão; 2) Qual a estrutura da fibra do algodão?;3) Qual oseu tamanho e diâmetro?

Em MOC, em relação à questão 1 (forma e/ ou organização da fibra de algodão), observou-se o comprimento, a forma variada da fibra e a sua camada de proteção à base de celulose (fibrilas) a qual se atribuia flexibilidade do fio. Isto permite uma descrição básica sobre a estrutura, forma/organização, tamanho, diâmetro e rigidez da fibra de algodão.

Em relação à estrutura da fibra de algodão (questão 2), evidenciou-se que a distinção (observação individual) da fibra só foi possível a partir da MEB e da MOC. Percebeu-se a cutícula associada à celulose (primeira camada da fibra), os espaços vazios deixados pela morte de protoplasma (segunda camada) e a extremidade alongada a qual não faz contato com a semente.

A olho nu abstraiu-se que, por conta do pequeno tamanho macroscópico (23-32 mm ou 23-32.000 $\mu \mathrm{m})$ e do diâmetro $(0,21 \mathrm{~mm}$ ou $210 \mu \mathrm{m})$ médios da fibra de algodão (questão 3), o emaranhado ou rede observada denota a sua flexibilidade em contraste com a sua rigidez. Tal arranjo possibilita a acomodação da fibra em pequeno espaço dentro do fruto, a qual pode ser tomada para os mais variados fins, a exemplo da industrialização. Depreendese que durante o amadurecimento da fibra há degeneração do protoplasma e a evaporação do conteúdo da seiva celular (lúmen). Isto resulta nas proteínas e sais que junto à celulose 
mantêm a rigidez da fibra que ainda é coberta por uma cutícula composta por gorduras, cera e pectinas. Isto possibilita a proteção da semente imatura e auxiliar em sua dispersão após seu desenvolvimento (TROTMAN, 1984).

Aspectos estruturais e funcionais da fibra de algodão podem ser discutidos e observados na prática posteriormente, como: observar e caracterizar a fibra em desenvolvimento (célula jovem), diferenciar os tipos de fibras, entre outros.

\section{O FIO DE CABELO}

Dependendo da raça, o diâmetro de um fio de cabelo humano pode variar de 15 a 120 $\mathrm{mm}(120.000 \mu \mathrm{m})$. O fio de cabelo é composto por três camadas: a primeira camada é a cutícula que contém várias subcamadas afastadas por um complexo de células (endocutícula, epicutícula e exocutícula); a segunda camada é denominada de córtex e é estruturada por um conjunto de células matriz com forma cilíndrica, sendo responsável pela produção de queratina e outras proteínas, a exemplo da melanina; a terceira camada e mais interna do cabelo é a medula, que em alguns tipos de cabelo pode não existir (POZEBON, DRESSLER \& CURTIUS, 1999).

O fio do cabelo observado a olho nu apresenta uma coloração amarronzada e formato uniforme. Em MEB, aumento de 10x, (fig. 06), distinguiu-se do filamento, a raiz e o material pastoso que a constitui. Com auxílio de um MOC, aumento de 10x (Fig.17) identificou-se com mais clareza formato arredondado do filamento e suas irregularidades. Com o aumento de 20x em MOC (fig. 18) visualizou-se a cutícula que envolve a parte interna do fio de cabelo, sendo esta estrutura responsável pela proteção contra ações físicas, químicas e biológicas. Com o aumento de 40x (fig. 19) em MOC, percebeu-se uma "massa de tecido" (matriz) dentro da raiz do folículo piloso, encarregada da produção e crescimento dos fios. Estes se assemelham com uma corda, com uma depressão no meio e bordas mais escuras (cutícula) (POZEBON; DRESSLER; CURTIUS, 1999).

Figuras 06, 07, 08, 09: Fio de cabelo (MEB, aumento de 10x) e MOC (aumentos de 4x; 10x; 20x), respectivamente.
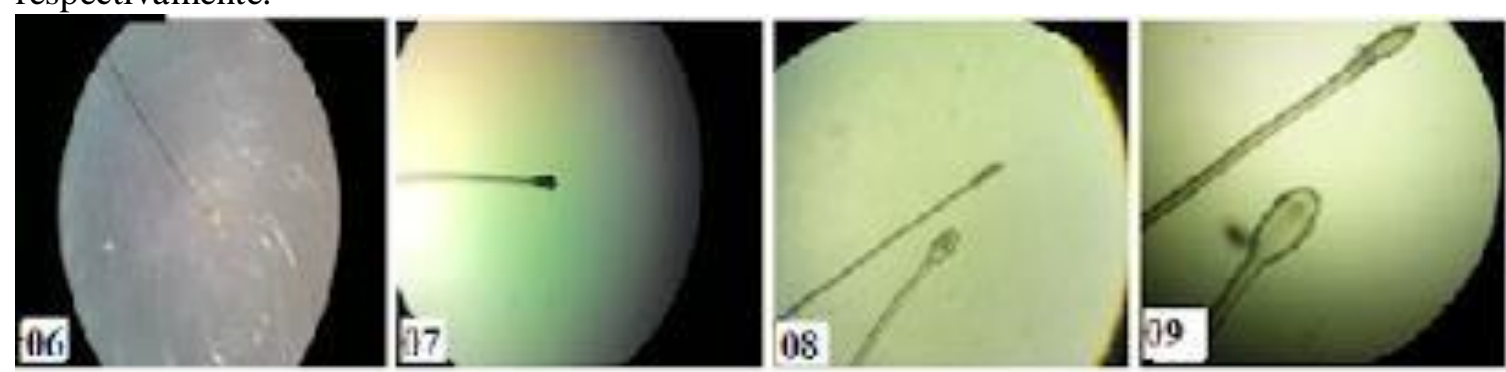

Fonte: Autores 
A partir da atividade prática com o fio de cabelo, tornou-se possível discutir as seguintes questões (quarteto 1): 1) Qual a forma e a estrutura do fio do cabelo? ; 2) O fio de cabelo é uma macro célula ou sua raiz?; 3) Como ocorre a formação do fio?; 4) Há alguma semelhança na sua formação com a fibra de algodão?

Em relação á primeira questão 1 (forma e a estrutura do fio de cabelo), a observação a olho nu evidenciou-se apenas a cor e formato uniforme e indistinto do filamento. Com auxilio de um MEB (aumento de 10x) distinguiu-se o conteúdo amorfo que compõe o bulbo ou folículo, possui cavidades e o formato arredondado do fio de cabelo. Em MOC, destacouse progressivamente a cutícula e o córtex do fio de cabelo, sob aumentos de 10 e 20x, com a queratina direcionada internamente a partir da raiz, como uma cordacoberta pela cutícula.

Quanto à questão 2 (O fio ou a raiz do cabelo é uma macro célula), trata-se de filamento queratinizado (anexo da pele) sintetizado pelos folículos (bulbo) que são pequenas estruturas macroscópicas (tecidos) contendo diferentes células com componentes glandulares e musculares. As células cilíndricas da matriz do folículo são responsáveis pela produção de queratina e outras proteínas, a exemplo da melanina.

Em relação à formação do fio de cabelo (questão 3), argumentou-se que as células musculares contribuem para manutenção da rigidez da cutícula, pois empurram para cima as células da matriz que morrem (perdem a alimentação na matriz) para serem substituídas por outras células. Acrescentou-se que as glândulas sebáceas drenam o filamento desde a raiz (folículo ou bulbo) com apoio das células musculares.

Quanto à questão 4 (fio do cabelo x fibra de algodão), abstraiu-se que, embora o filamento queratinizado possa ter 15 a 120 mm (15 a 120000 $\mu \mathrm{m})$ de diâmetro, a percepção acerca da sua estrutura básica (a cutícula e o córtex) depende da microscopia (aumentos de 20 e 40x) cuja formação ocorre por desidratação (folículo piloso) que pode assemelhar ao processo de maturação da fibra de algodão (drenagem referida na questão anterior). Essa cutícula é responsável pela proteção contra ações de agentes físicos, químicos e biológicos, assim como é feita revestimento de celulose da fibra de algodão.

\section{O ÓVULO DA BANANA}

O óvulo da bananeira (Musa spp.) é bi tegumentar e anátropo. Ele é formado no ovário ínfero, tri carpelar, tri locular da flor de bananeira. A flor da Musa spp. tem placentação axial e cada lóculo do ovário possui um ou vários óvulos (BARBOSA, 2015).

Os óvulos da banana (Musa spp.), observados a olho nu, apresentaram-se apenas como pequenos pontos marrons escuros ligadas ao centro do fruto a partir de uma das suas extremidades. Trata-se das paredes dos lóculos e/ou ovários em que os óvulos estão presos 
ao seu eixo (placentação axial). Com pequena ampliação em MEB (aumento de 10x), as ligações entre o óvulo, o centro do fruto e sua extremidade foram visualizadas (fig.10). Em MOC, com ampliação de 10x e 20x (fig. 11 e 12), evidenciaram-se as camadas externa e internas ou (in) tegumentos (primina e secundina), a nucela e ovário do óvulo (região escura central). Observou-se também o funículo alongado com grande curvaturacom função de unir os (in) tegumentos, formando uma linha de soldadura, a rafe (VIDAL \& VIDAL, 2003).

Figura 10,11 e 12: óvulos da banana (Musa spp.) visualizados em MEB (aumento de 10x) e MOC (4x e 10x,) respectivamente.

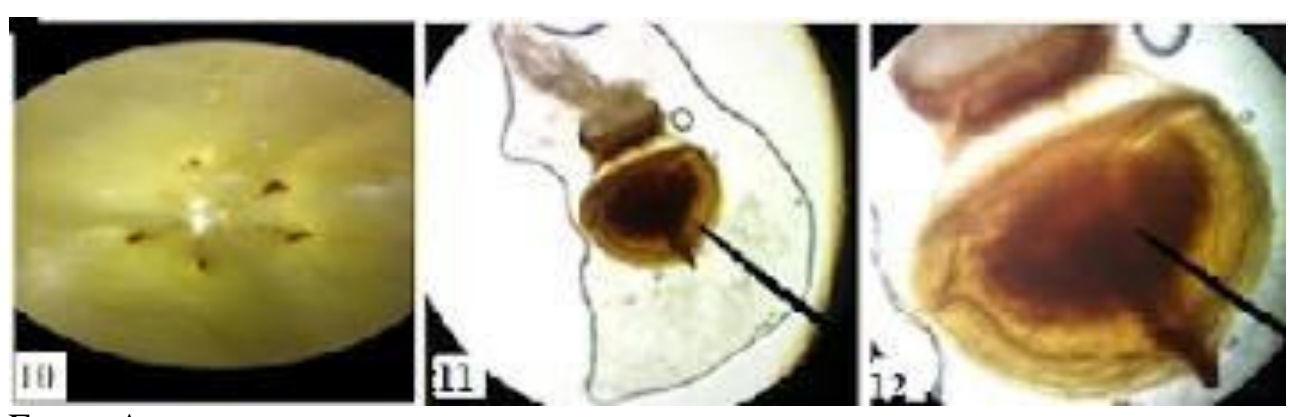

Fonte: Autores

A partir da atividade prática com o óvulo da banana (Musa ssp.), tornou-se possível discutir as seguintes questões (quarteto 2): 1) Qual a estrutura/organização do óvulo da banana?; 2) Qual o seu tamanho e a sua forma?; 3) A óvulo da banana não é fertilizado por quê?; 4) Quantos óvulos existem em uma banana?

Em relação à estrutura/organização do óvulo da banana (questão 1), observou-se que eles se organizam concentricamente ao longo do fruto (placentação axial) por estarem presos aos lóculos (um ou mais óvulos) que preenchem o ovário (trilocular) em que sua quantidade depende da quantidade de flores na inflorescência. Em especial, identificaram-se as estruturas com tamanho maior (nível tecidual) como (in) tegumentos externo e interno (a primina e a secundina), a nucela, o funículo, a rafe e o ovário; outras estruturas como saco embrionário, antípodas, sinérgides e núcleos polares não foi possível observar por conta da limitação na microscopia óptica.

Quanto ao tamanho/forma (questão 2), mostrou-se que o óvulo tem cerca de $1 \mathrm{~mm}$ $(1000 \mu \mathrm{m})$ e tem formato oval (fig. 11 e 12) que lembra um "pião" ${ }^{1}$. Trata-se de um óvulo não fecundado, por conta da atrofia em uns dos órgãos reprodutivos da flor bissexual (gineceu ou androceu), conforme assinala o autor Barbosa (2015).

\footnotetext{
${ }^{1}$ Objeto afunilado de madeira ou plástico usado em brincadeiras pelas crianças com ponta de ferro voltada para baixo e extremidade superior com encaixe para a mão ou de uma corda que o faz girar.
} 
Em relação à fertilização (questão 3), os cruzamentos entre espécies e subespécies do gênero Musa, em processos de domesticação, foram selecionados aquelas em que a reprodução assexuada prevalecia com esterilização da flor, abortamento dos óvulos e desenvolvimento do fruto por partenocarpia. Assinalou-se ainda que a germinação da semente seja limitada até nas espécies nativas em decorrência de seu (in) tegumento rígido que dificulta a entrada de água para ativar o metabolismo (BARBOSA, 2015).

No que tange à questão 4 (número de óvulos que contém numa banana), assinala-se que a quantidade de óvulos contidos num fruto depende da quantidade de flores que compunha a inflorescência, pois cada flor pode ter um ovário tri carpelar, ou seja, uma flor com três ovários, cada ovário tem três lóculos (trilocular) em que cada um pode ter uma ou mais óvulos. Assim, podemos depreender que o óvulo da banana é um órgão vestigial, já que esta prescinde da reprodução sexuada. Assuntos que excedem a este trabalho como resistência a pragas para espécies comestíveis de banana e fertilização de embriões a partir da engenharia genética podem ser discutidas a "posteriori", dentre outras.

\section{O ÓVULO VEGETAL}

O óvulo é formado na placenta, situada na região interna do carpelo. Mede de cerca de 100 micrômetros $(\mu \mathrm{m})$ até poucos milímetros $(\mathrm{mm})$, e, geralmente, tem forma ovoide, a qual está associada o seu nome. O óvulo é um corpúsculo onde se forma o gameta feminino, e, após a fecundação, se transforma em semente. Cada óvulo é composto pelas seguintes regiões: nucela, funículo, que une a placenta, calaza que une o funículo a nucela (região basal) e os (in) tegumentos que envolvem a nucela e deixam, na região superior, uma abertura que é a micrópila por onde penetra o grão de pólen. A nucela é um tecido sem vasos que tem a função de nutrir o embrião. A placenta é a região do ovário onde se inserem os óvulos, podendo apresentar um mais lóculos (STRASSBURGER, 1994; VIDAL \& VIDAL, 2003).

No seu interior do óvulo está o saco embrionário com a seguinte composição: seis células (uma oosfera, duas sinérgides e três antípodas) e dois núcleos (os núcleos polares geralmente se fundem formando o mesocisto ou núcleo secundário do saco embrionário que produz o albume). A oosfera é o gameta feminino que, após a fecundação, vai formar o embrião da semente (STRASSBURGER, 1994; VIDAL \& VIDAL, 2003).

De acordo com curvatura do funículo e a torsão da nucela, os óvulos são classificados em: ortótropo, anátropo, campilótropo e anfítropo. O óvulo ortótropo é reto e o funículo, o saco embrionário, a calaza, o hilo e a micrópila (voltada para cima) estão dispostos em linha reta; o óvulo anátropo tema micrópila em posição oposta à calaza, a qual se aproxima da 
placenta e do funículo que é alongado com grande curvatura que une os (in) tegumentos, formando uma linha de soldadura, a rafe; o óvulo campilótropo tem eixo da nucela e (in) tegumentos curvados em ferradura e a calaza não fica oposto à micrópila; o óvulo anfítropo tem o funículo encurvado com eixo reto paralelo à placenta e a calaza não está oposta à micrópila (VIDAL \& VIDAL, 2003).

A maioria dos óvulos de angiospermas apresentam dois tegumentos, sendo interno chamado de secundina e o externo de primina (monocotiledôneas e dicotiledôneas), enquanto as gimnospermas, geralmente tem um tegumento apenas (GONZALEZ, 2000).

O óvulo da flor da erva beijo-de-frade (Impatiens balsamina L.), visualizado a olho nu, possui semelhança com uma semente pequena e seca. Ele possui formato oval, com paredes externas aparentemente uniformes e coloração verde escura. $\mathrm{O}$ seu formato pode ser decorrente de uma adaptação voltada para o ajuste ao espaço onde ele é formado (entre a placenta e o carpelo). O óvulo observado em MEB (aumento de 10x) (fig. 13) apresentou somente uma heterogeneidade na coloração, mantendo-se, ademais, a caracterização feita a olho nu. A partir da observação em MOC com aumento de 4x (fig. 14), identificaram-se sinais (manchas de tecido) de uma estrutura parecida com tubo (funículo). Sob aumento de 10x em MOC, o funículo foi visualizado como grande curvatura cuja função é ligar o óvulo com placenta do ovário (fig. 25). Esta estrutura une as camadas externa e interna do óvulo que são responsáveis por suas atividades metabólicas (STRASSBURGER, 1994; VIDAL \& VIDAL, 2003).

Observou-se (fig. 14 e 15) o formato mais retangular do óvulo (aumentos de 4x e 10x) e a camada externa (primina) mais nítida com aumento de 10x. Isto possibilita uma melhor compreensão sobre o seu papel de proteção das estruturas internas celulares aos fatores externos, como também da regulação do fluxo de substâncias para o interior do óvulo. Verificou-se ainda que a camada externa do óvulo seja mais espessa do que a interna devido a uma maior lignificação (STRASSBURGER, 1994; VIDAL \& VIDAL, 2003).

Figuras 13, 14, 15: óvulo vegetal visualizado em MEB (aumento de 10x) e em MOC (aumentos de 4x; 10x), respectivamente.

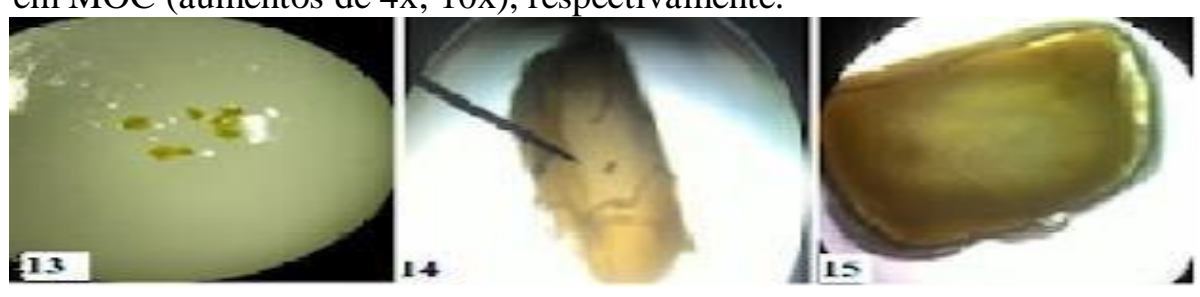

Fonte: Autores

A partir da atividade prática com o óvulo da flor da erva beijo-de- frade (Impatiens balsamina L.) tornou-se possível discutir as seguintes questões (quarteto 3): 1) Em que 
região da flor é formada; 2) Qual a forma e a estrutura do óvulo; 3) Qual o seu tamanho?;4) Alguns óvulos são microscópicos e outros macroscópicos?

Em relação à localização e formação do óvulo na florda erva beijo-de-frade (questão 1), foi evidenciado (a olho nu) e discutido sobre a sua disposição no ovário com formação a partir da placenta, situada na região interna do carpelo (VIDAL \& VIDAL, 2003).

Quanto á forma/estrutura do óvulo (questão 2) assinalou-se que este tem forma ovoide ligeiramente retangular (observação em MEB sob aumento de 10x). Observou-se apenas em MOC (aumentode 4x), a camada externa (primina), o funículo (mancha próximo ao indicador da imagem), como curvatura que circunda o óvulo (figura 14), formando uma linha de soldadura, a rafe, (fig. 15). (STRASSBURGER, 1994; VIDAL \& VIDAL, 2003). Ressalvou-se que a primina tem a função de proteger o óvulo dos agentes externos (físicos, químicos e biológicos) e de regular do fluxo de substâncias para o seu interior.

Evidenciou-se que o tamanho do óvulo é de cerca de $0,5 \mathrm{~mm}$ ou $500 \mu \mathrm{m}$ (questão 3), o que sinaliza ser um padrão médio de tamanho entre as fanerógamas (plantas com flores). Destacou-se que há uma limitação nos estudos ou mapeamento acerca do tamanho micro ou macroscópico do óvulo ou gametófito feminino da flor (questão 4), porém assegurou-se que com o surgimento da flor nas gimnospermas e angiospermas, esse órgão diminuiu o seu tamanho. As espécies mais restritas a herbivoria tende a ter óvulos maiores e com facilidade de atração para os polinizadores (JUDD et al., 2009; GUREVITCH, SCHEINER \& FOX, 2009).

\section{O GRÃO DE PÓLEN}

A descrição acerca da forma e tamanho do tecido germinativo vegetal (gametófito masculino) pode ficar mais compreensível a partir da localização dele no órgão reprodutivo (flor). Para isto, usa-se como exemplo as flores de brinco- de- princesa e do hibisco que medem cerca de $10 \mathrm{~cm}$ e $20 \mathrm{~cm}$, respectivamente (VIDAL \& VIDAL, 2003).

O grão de pólen é uma estrutura microscópica (entre 0,01 a 0,35 mm ou 10 a 350 $4 \mathrm{~m}$ ) com número haploide de cromossomos. Em geral, tem coloração amarelada e formato variado (arredondado ou ovoide), que é específico para cada espécie vegetal. Na flor, os grãos de pólen se formam a partir das células-mãe (megásporos ou células esporogênicas), dentro das anteras. Quando chegam à maturidade, os grãos de pólen podem se organizar na forma de tétrades ou de conjuntos maiores (polínios), ou permanecer isolados (VIDAL \& VIDAL, 2003; JUDD et al., 2009).

O grão de pólen é constituído por duas membranas: a externa, denominada de exina, que dá rigidez ao grão de pólen e possui poros germinativos, e a interna, conhecida como 
intina, onde acontecem os processos correspondentes à emissão, alongamento, desenvolvimento e a formação do tubo polínico. Dentro do grão de pólen há dois núcleos: um menor, o reprodutivo, e outro maior, com funções nutricionais (PIO, 2003).

É uma célula microscópica com tamanho menor que $0,35 \mathrm{~mm}$ ou $350 \mu \mathrm{m}$, onde não é possível visualizá-lo a olho nu. O agrupamento do grão de pólen é observado a olho nu, mas sem diferenciar sua forma de organização que, em suagrande maioria, forma tétrades (grupo de 4). Estes grupos podem ser observados através MEB com aumento de 10x (fig. 16). Foi evidenciado com pouca clareza, centenas de grãos de pólen individualizados em MOC, sob aumento de 4x (fig. 17). Em MOC, percebeu-se o formato oval dos grãos de pólen com aumento de 10x (fig. 18) e com 20x (fig. 19) identificou-se a membrana externa e ligeiro enrugamento que sinalizam os poros germinativos que possibilitam a rigidez ao grão de pólen e sua aderência ao estigma do gineceu de uma flor (VIDAL \& VIDAL, 2003; PIO, 2003; JUD et al., 2009).

Figuras 26, 27, 28 e 29: grão de pólen visualizado em meb (10x) e em moc (4x; 10x; 20x), respectivamente

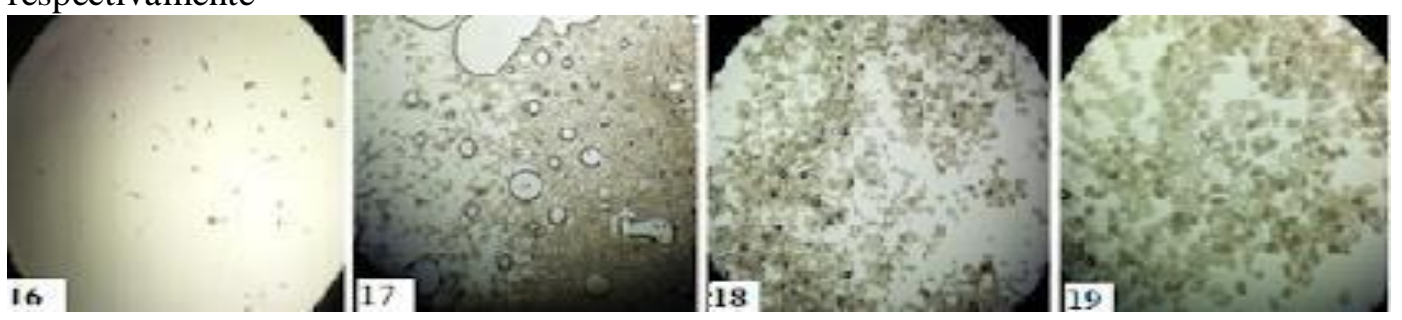

Fonte: Autores.

A partir da atividade prática realizada com grão de pólen da flor beijo-de-frade (Impatiens balsamina L), tornou-se possível discutir as seguintes questões (quarteto 4): 1) Onde se localiza o grão de pólen na flor?;2) Como se organizam os grãos de pólen e qual a sua forma?; 3) Qual a estrutura e o tamanho do grão de pólen?; 4) O grão de pólen e o óvulo são os gametas responsáveis pela fecundação no vegetal?

Em relação à localização do grão de pólen (questão 1), observou-se que ele se localiza na antera da flor, numa região chamada de teca (bolsa). A antera é uma estrutura achatada que fica na ponta do filete formando o estame. O conjunto de estame forma o androceu da flor (VIDAL \& VIDAL, 2003).

Quanto à questão 2, que diz respeito ao formato e organização do grão de pólen, na flor da erva de beijo- de- frade (Impatiens balsamina L), o grão de pólen tem formato oval e está organizado em tétrades, formando um aglomerado (VIDAL \& VIDAL, 2003; JUD et al., 2009). 
Sobre o tamanho e estrutura do grão de pólen (questão 3), em MOC foi possível depreender apenas que ele tem tamanho menor que $0,35 \mathrm{~mm}(350 \mu \mathrm{m})$ e a sua membrana externa enrugada e rígida com a função de aderir ao estigma do gineceu da flor. A membrana interna (intina) e seus núcleos reprodutivos e nutritivos não foram observados (VIDAL \& VIDAL, 2003; PIO, 2003; JUD et al., 2009).

Quanto à atribuição de função de gameta ao grão de pólen e ao óvulo (questão 4), afirmou-seque uma flor feminina é estruturada basicamente por estigma, estilete e ovário (ver fig. 5) e o óvulo é o gametófito feminino composto por (in) tegumentos, nucela, micrópila e suas células internas (antípodas, núcleos polares, oosfera e sinérgides) (ver fig. 6). O grão de pólen é o gametófito masculino da flor que ao chegar ao estigma, desce pelo estilete e se transforma no tubo polínico que adentra a micrópila do óvulo ao encontro das oosferas. Forma se duas células ( $1^{\circ}$ e $2^{\circ}$ anterozoides ou microgametas) no tubo polínico; uma delas fecunda oosfera dando origem ao embrião diploide (2n) e a outra se une aos dois núcleos polares e forma um tecido triploide (3n) que vai nutrir o embrião (endosperma). Então as células reprodutivas masculinas e femininas são os anterozoides e as oosferas. Outras questões em nível estrutural e funcional podem ser discutidas, tais como: a identificação da membrana interna (intina) e seus núcleos reprodutivos, os processos biológicos envolvidos no amadurecimento e liberação do pólen, a composição do pólen (intina e exina) e o uso do pólen na taxonomia etc. (VIDAL \& VIDAL, 2003; PIO, 2003; JUD et al., 2009).

\section{USO DA FUNCIONALIDADE}

1) Para a questão "Como se explica a forma ("garrafinha") ou organização dos alvéolos no endocarpo da laranja e a produção do conteúdo liquido" (terceto 1), depreendeuse que a organização espacial dos alvéolos dentro do endocarpo pode está associado a sua função de prender aos demais alvéolos, deixar espaços para alojamento das sementes e permitir a realização da atividade metabólica (respiração e a síntese do etileno);

2) Em relação à questão "Como se explica a forma e/ ou organização da fibra de algodão"?(terceto 1), explicou-se que a sua visualização sob a forma de um emaranhado ou rede de fio denota a flexibilidade ou arranjo da fibra de algodão, e, ao mesmo tempo, a sua resistência. Acredita-se que tal caracterização possibilita a configuração da fibra em pequeno espaço dentro do fruto, bem como na representação espacial tomada para os mais variados fins, a exemplo da industrialização. Acrescentou-se que a flexibilidade, em particular, ocorre devido a processos metabólicos responsáveis pelo amadurecimento da fibra em que há degeneração do protoplasma, a evaporação do conteúdo protoplasmático e da seiva celular. Isto resulta nas proteínas e sais que

Cidadania em Ação; Revista de Extensão e Cultura, Florianópolis (SC), v. 3, n. 2, jul./dez. 2019. 
junto à celulose mantêm a rigidez da fibra que é coberta por uma cutícula composta por gorduras, cera e pectinas. Isto possibilita a proteção da semente imatura e auxilia em sua dispersão após seu desenvolvimento, que explica a questão “Qual a estrutura da fibra do algodão?” (terceto 1);

3) Quanto à questão 2, quarteto 1 (O fio de cabelo é uma macro célula ou sua raiz?), esclareceu-se que o filamento queratinizado (anexo da pele) é sintetizado pelos folículos pilosos (bulbo) que são pequenos órgãos macroscópicos contendo diferentes células com componentes glandulares e musculares. Em relação à questão 3, quarteto 1 (Como ocorre a formação do fio de cabelo?), ressaltou-se que um conjunto de células da matriz do folículo, com forma cilíndrica, produz a queratina e outras proteínas que participam da estruturação do fio. Para isso, esclareceu-se que as glândulas sebáceas drenam o filamento do cabelo desde a raiz (folículo ou bulbo);

4) Quanto ao tamanho do óvulo da banana Musa spp. (questão 2, quarteto 2), afirmou-se que óvulo tem cerca de $0,5 \mathrm{~mm}(500 \mu \mathrm{m})$. Acrescentou-se que os pontos escuros erroneamente chamados de semente são óvulos não fecundados, por conta da atrofia em uns dos órgãos reprodutivos da flor bissexual (gineceu ou androceu). Em relação à questão 3, quarteto 2 (O óvulo da banana não é fertilizado por quê?), explicaram-se que os cruzamentos entre espécies e subespécies do gênero Musa, em processos de domesticação, foram selecionados aquelas em que a reprodução assexuada prevalecia, uma vez que a germinação da semente é limitada nas espécies nativas em decorrência de um (in) tegumento rígido que dificulta a entrada de água para ativar o metabolismo;

5) No que tange à questão 2, quarteto 3 (Qual a forma e a estrutura do óvulo), assinalou-se que o formato oval do óvulo da flor da erva beijo-de-frade (Impatiens balsamina L.) pode ser decorrente de uma adaptação voltada para o ajuste ao espaço onde ele é formado (entre a placenta e o carpelo);

6) Quanto á atribuição de função de gameta ao pólen e ao óvulo (questão 4, quarteto 4- O grão de pólen e o óvulo são os gametas responsáveis pela fecundação no vegetal?), esclareceu-se que uma flor feminina é estruturada basicamente por estigma, estilete e ovário (ver fig. 5) e o óvulo é o gametófito feminino composto por (in) tegumentos, nucela, micrópila e suas células internas (antípodas, núcleos polares, oosfera e sinérgides). O grão de pólen é o gametófito masculino da flor que ao chegar ao estigma, desce pelo estilete e se transforma no tubo polínico que adentra a micrópila do óvulo ao encontro das oosferas. Forma se duas células $\left(1^{\circ}\right.$ e $2^{\circ}$ anterozoides ou microgametas) no tubo polínico; uma delas fecunda oosfera e dá origem ao embrião diploide (2n) e a outra se une aos dois núcleos polares e forma o endosperma (3n) que vai nutrir o embrião. Então, as células reprodutivas masculinas e femininas são os anterozoides e as oosferas, respectivamente; 


\section{CONSIDERAÇÕES FINAIS}

A partir do presente trabalho foi possível caracterizar o tamanho, a estrutura (óvulo, pólen, cabelo etc.) e a forma e/ou organização estruturas pluricelulares microscópicas/ macroscópicas (grão de pólen e o óvulo da flor da erva beijo-de-frade) ou pluricelulares macroscópicas pequenas (fio de cabelo, óvulo da banana), células macroscópicas (alvéolo da laranja e a fibra de algodão), entre outras características. Percebeu-se que cada célula ou tecido tem propriedades específicas (arranjo espacial do alvéolo de laranja e da fibra de algodão, ambos dentro do fruto, enrugamento do grão de pólen, abertura da micrópila do óvulo etc.) que se relaciona como seu ciclo de vida, hábitat, proteção, movimento, alimentação etc. e que são fundamentais para a sobrevivência da espécie.

A observação de macro células, como alvéolos da laranja e óvulo, por exemplo, em Microscopia Estereoscópica Binocular (MEB) e Microscopia Óptica Comum (MOC) possibilitou uma caracterização mais geral acerca das estruturas externas. Uma ampliação a partir de 20x limita a nitidez da amostra devido à turbidez gerada pelo aumento campo visual para estruturas macroscópicas. As observações com aumentos maiores até 20x favoreceu a identificação de pequenas estruturas vivas (tegumento, funículo e a nucela do óvulo, a matriz do folículo piloso etc.), salvo alguns exemplos em que a ampliação de até 40x foi adequada para o referido fim.

Em geral, sinalizou-se que conceitos resultantes das atividades práticas como forma/tipologias de pólen, óvulo, ovário, fibra de algodão etc. podem se usados como base para estudos de classificação de taxonomia de seres vivos, diversidade, ecologia e evolução. Estes termos interferem na definiçãodo tecido, órgão ou sistema orgânico do ser vivo, bem como na sua funcionalidade, tanto nas suas estruturas individuais (célula e tecido), quanto na sua integralidade (sistemas). Por isso, os resultados das atividades práticas foram suficientes para explicar algumas questões, entretanto, para outras questões, foi necessário recorrer a uma explicação teórica, devido a não evidenciação de dados concretos capazes de contribuir para um esclarecimento de questões mais amplas, a exemplo da explicação sobre a variação de tamanho em óvulos, ou mesmo para explicar porque a maioria das células é microscópica e apenas algumas são macroscópicas, entre outras.

Esse trabalho é de fundamental importância para os discentes de Engenharia de Pesca, de Engenharia Sanitária Ambiental e áreas afins, pois contribuiu para: 1) a distinção elementos celulares básicos em diferentes escalas (olho nu, MEB e MOC); 2) identificação das limitações das técnicas usadas quanto inobservância de estruturas celulares que dependem do uso de reagentes ou microscopia de maior alcance; 3) embasamento para estudo de disciplinas afins; 4) visualização de estruturas que conheciam apenas no plano 
teórico ou lhes eram desconhecidos (diferenciação entre tecidos e células reprodutivas vegetais, parede celular etc.); 5) assimilação de conceitos novos (composição dos alvéolos da laranja e da fibra de algodão etc.); 6) vinculação do trabalho prático como base para participação de projetos de pesquisa etc.

Enfim, constatou-se que há necessidade continuidade do trabalho extensionista, no sentido do aperfeiçoamento e/ou criação de novas de práticas laboratoriais, pois muitas das questões levantadas carecem de explicações complementares (teóricas e/ou práticas). Isto pode favorecer a uma melhor distinção entre os limites micro e macroscópicos das células/seres vivos, bem como a uma maior compreensão sobre as estruturas e funções. 


\section{REFERÊNCIAS}

BARBOSA, A. O. Aspectos reprodutivos e fertilidade em bananeiras diplóides e triplóides. 2012. Dissertação (mestrado)-Universidade Federal do Recôncavo Baiano. 2015.

CALBO, A. G.; MORETTI, C. L.; HENZ, G.P. Comunicado Técnico: Respiração de Frutas e Hortaliças. EMBRAPA. Brasília, DF. nov., 2007.

AUTOR. Estudo de Conceitos de Seres Vivos nas Séries Iniciais. 2010. Dissertação (mestrado)- Universidade Federal da Bahia. Salvador, 2010.

AUTOR. Estudo de Conceitos de Estrutura e Funcionalidade de Seres Vivos no Ensino Fundamental I. 2014. Tese (doutorado) - Universidade Federal da Bahia. Salvador, 2014.

FERRI, M. G. (Coord.) Fisiologia Vegetal. v. 1.; v. 2. 2. ed. São Paulo: EPU, 1985, 361p.

GONZALEZ, A. M. Tesisdoctoral: Estudios Anatómicos em los géneros Piriqueta y Turnera (Turneraceae). Universidad Nacional de Córdoba, Argentina, 2000.

GUREVITCH J; SCHEINER, S. M.; FOX, G. A.. Ecologia Vegetal. 2. ed. Porto Alegre: Editora Artmed, 2009.

JUDD, W. S., CAMPBELL, C. S.; KELlOGG, E. A.; STEVENS, P. F.; DONOGHUE, M. J. . Sistemática Vegetal: Um Enfoque Filogenético. [s.1.]: Artmed Editora, 2009. 632 p., 3. ed.

PIO L. A. S. Viabilidade do pólen de citros em diferentes condições de armazenamento. 2003. Dissertação (mestrado)-Universidade Federal de Lavras. Lavras, 2003.

POZEBON, D.; DRESSLER, V. L.; CURTIUS, A. J. Análise de cabelo: uma revisão dos procedimentos para a determinação de elementos traços e aplicações. Revista Química Nova. Florianópolis, v. 22, n.6, 1999.

RIBEIRO, M. S. L.; BARBERI, M. Análise palinológica: fundamentos na perspectiva na pesquisa arqueológica. Goiânia, v.3, n.2, p. 261-290, 2005.

STRASSBURGER, E. Tratado de Botánica. 8. ed. Barcelona: Omega, 1088 p., 1994.

TROTMAN, E.R. Dyeing and Chemical Technology of Textile Fibers, 6. ed., London: Edward Arnold, 1984.

VIDAL, W. N. VIDAL, M. R. R. BOTÂNICA - Organografia: quadros sinóticos ilustrados de fanerógamos. Viçosa: UFV, 2003. 124 p., 4. ed. rev. ampl. 